\title{
Synthesis, antibacterial and antifungal activity of some derivatives of 2-phenyl-chromen-4-one
}

\author{
SAYED ALAM \\ Department of Chemistry, Rajshahi University of Engineering and Technology, Rajshahi 6204, Bangladesh \\ Present address: Department of Life Science and Biotechnology, Shimane University, Matsue, Shimane 690- \\ 8504, Japan \\ e-mail: alam_sms@yahoo.com
}

MS received 28 January 2004; revised 15 September 2004

\begin{abstract}
Some derivatives of 2-phenyl-chromen-4-one (flavone ring) have been synthesized and tested for antibacterial and antifungal activities along with their chalcone precursors against four human pathogenic bacteria and five plant mould fungi. The structures of the synthesized compounds were elucidated by UV, IR and ${ }^{1} \mathrm{H}$ NMR spectroscopic techniques, and elemental analysis. The antibacterial and antifungal screens of the synthesized compounds were performed in vitro by the filter paper disc diffusion method and the poisoned food technique.
\end{abstract}

Keywords. Flavone; 2-phenyl-chromen-4-one; antibacterial and antifungal activity; inhibition zone.

\section{Introduction}

The flavone ring (2-phenyl-chromen-4-one) system is of considerable interest due to several biological effects including antibacterial ${ }^{1}$ and antifungal activity. ${ }^{2,3}$ A survey of the literature provides information that flavonoids containing methylenedioxy group $\left(-\mathrm{O}-\mathrm{CH}_{2}-\mathrm{O}-\right)$ widely occur in natural plant pigments. ${ }^{4}$ The flavonoids are an group of natural products founds in fruits, vegetables, nuts, seeds and flowers as well as in teas and wines, and are an important constituent of human diet. They have been demonstrated to possess many biological and pharmacological activities such as antibacterial, antifungal, antiviral, antioxidant, anti-inflammatory, antimutagenic and antiallergic activities and inhibitory activities on several enzymes. ${ }^{5,6}$ Our previous articles ${ }^{7-10}$ have reported the antibacterial and antifugal effects of the flavone ring system (2-phenyl-chromen-4-one) containing furan, prenyl, methoxyl and hydroxyl group in various positions. This paper reports the syntheses of two derivatives of 2-phenyl-chromen-4-one (flavone) containing methylenedioxy group (6 and 7) from their corresponding chalcones (4 and 5) by using different $\mathrm{DMSO} / \mathrm{I}_{2}$, diphenyl sulphide and DDQ as oxidizing agents. Both the flavones and their corresponding chalcones were screened in vitro for their antibacterial and antifungal activity against four human pathogenic bacteria, viz., Sarcina lutea
$\left(\mathrm{G}^{+}\right)$, Bacilus subtillis $\left(\mathrm{G}^{+}\right)$, Shigella dysenteriae $\left(\mathrm{G}^{-}\right)$, Pseudomonas aeruginosa $\left(\mathrm{G}^{-}\right)$and five plant and mould fungi, viz. Colletotrichum gloeosporioides Penz., Candida albicans, Aspergillus niger, Aspergillus flavus and Penicillium sp.

\section{Experimental}

\subsection{Materials, methods and instruments}

Melting points were recorded on a Gallenkamp apparatus and are uncorrected. IR spectra $(\mathrm{KBr})$ were measured using a Shimadzu, DR-8001 spectrophotometer, ${ }^{1} \mathrm{H}$ NMR spectra $\left(\mathrm{CDCl}_{3}\right)$ on a Brucker WH $400 \mathrm{MHz}$ instrument with TMS as internal standard and UV spectra $(\mathrm{MeOH})$ on a LKB 4053 spectrophotometer. The chemical used was purchased from Aldrich Chemical Company (Tokyo, Japan). Purity of the compounds was checked by TLC.

\subsection{Synthesis of 3-benzo[1,3]dioxol-5-yl-1-(2- hydroxy-phenyl)-propenone (2'-hydroxy-3, 4- methylenedioxyhalcone, 4)}

A mixture of 2-hydroxyacetophenone (1, $20 \mathrm{mmol}$, $2.72 \mathrm{~g})$ and 3,4-methylenedioxybenzaldehyde (3, $1.1 \mathrm{~N}, 3.30 \mathrm{~g})$ in ethanolic solution of $\mathrm{KOH}(5 \%$, $15 \mathrm{ml}$ ) was kept at room temperature for about $75 \mathrm{~h}$. The reaction mixture was diluted with ice-cold water, 
acidified with cold dil. $\mathrm{HCl}$ and extracted with ether. The ether layer was washed with water, dried over anhydrous $\mathrm{Na}_{2} \mathrm{SO}_{4}$ and evaporated to dryness. The reaction mixture was subjected to column chromatography over silica gel. The elution was done with benzene-acetone $(10: 1)$ and crystallized from ether as pale yellow crystals $(4.09 \mathrm{~g})$, yield $68 \%$, m.p. $124-127^{\circ} \mathrm{C}, R_{f} 0 \cdot 61$ (benzene : acetone; $8: 1$ ).

Analysis (found) C, 71.92; H, 4.22\%; (Calculated for $\mathrm{C}_{16} \mathrm{H}_{12} \mathrm{O}_{4}$ ): C, $71.64 ; \mathrm{H}, 4.51 \%$.

$\mathrm{UV} \gamma_{\max }^{\mathrm{MeOH}}: 230,265$ and $355 \mathrm{~nm}$.

IR $v_{\max }^{\mathrm{KBr}}: 3071,2907,2616,1640,1617,1569$, $1534,1504,1490,1459,1439,1407,1372,1354$, $1336,1310,1284,1271,1242,1203,1161,1130$, 1098, 1038, 1026, 975, 935, 916, 867, 816, 805, $759,748,721,666,623 \mathrm{~cm}^{-1}$.

${ }^{l} \mathrm{H}$ NMR $\left(\mathrm{CDCl}_{3}\right): \delta 5.74\left(s, 2 \mathrm{H},-\mathrm{O}-\mathrm{CH}_{2}-\mathrm{O}-\right), 6.65$ $\left(d, 1 \mathrm{H}, J=8.7 \mathrm{~Hz}, \mathrm{C}_{5}-\mathrm{H}\right), 6.83\left(s, 1 \mathrm{H}, \mathrm{C}_{2}-\mathrm{H}\right), 6.92$ $\left(d, 1 \mathrm{H}, J=8.7 \mathrm{~Hz}, \mathrm{C}_{6}-\mathrm{H}\right), 7 \cdot 01-7.07\left(m, 1 \mathrm{H}, \mathrm{C}_{5}{ }^{\prime}-\mathrm{H}\right)$, $6.97\left(d, 1 \mathrm{H}, J=9 \mathrm{~Hz}, \mathrm{C}_{3}{ }^{\prime}-\mathrm{H}\right), 7 \cdot 31-7.37(m, 1 \mathrm{H}$, $\left.\mathrm{C}_{4}{ }^{\prime}-\mathrm{H}\right), 7.41\left(d, 1 \mathrm{H}, J=16 \mathrm{~Hz}, \mathrm{C}_{\alpha}-\mathrm{H}\right), 7.60(d, 1 \mathrm{H}$, $\left.J=9 \mathrm{~Hz}, \mathrm{C}_{6}^{\prime}-\mathrm{H}\right), 8.01\left(d, 1 \mathrm{H}, J=16 \mathrm{~Hz}, \mathrm{C}_{\beta}-\mathrm{H}\right)$, $11.58\left(s, 1 \mathrm{H}, \mathrm{C}_{2}-\mathrm{OH}\right)$.

\subsection{Synthesis of 2-benzo[1,3]dioxol-5-yl-chromen-} 4-one (3', 4'-methylenedioxyflavone, 6) using $\mathrm{DMSO} / \mathrm{I}_{2}$

The chalcone $(4,1.5 \mathrm{mmol}, 402 \mathrm{mg})$ was suspended in dimethyl sulphoxide (DMSO, $10 \mathrm{ml}$ ) and a crystal of iodine ${ }^{11}$ was added to it. The mixture was refluxed for $20 \mathrm{~min}$ on a silicon oil bath and diluted with water. The solid obtained was filtered off and washed with $20 \%$ aq. sodium thiosulphate. It was purified by preparative TLC over silica gel $\mathrm{GF}_{254}$ using hexaneacetone $(10: 1)$ as developing solvent and crystallized from ether as yellow needles $(247 \mathrm{mg}$ ), yield $61.50 \%$, m.p. $131-132^{\circ} \mathrm{C}, R_{f} 0 \cdot 59$ (benzene-acetone; $10: 1$ ). It gave blue fluorescence in UV light and positive $\mathrm{Mg} / \mathrm{HCl}$ test.

Analysis (found): C, 72.55; H, 3.51\%; (Calculated for $\mathrm{C}_{16} \mathrm{H}_{10} \mathrm{O}_{4}$ ): C, $72 \cdot 18 ; \mathrm{H}, 3 \cdot 79 \%$.

$\mathrm{UV} \lambda_{\max }^{\mathrm{EtOH}}: 232,281$ and $370 \mathrm{~nm}$.

IR $\lambda_{\max }^{\mathrm{KBr}}: 2922,1647,1597,1569,1544,1473$, $1446,1430,1381,1346,1326,1296,1266,1245$, $1219,1126,1151,1110,1025,941,918,879,862$, $849,833,811,778,760,747,681 \mathrm{~cm}^{-1}$.

${ }^{1} \mathrm{H}$ NMR $\left(\mathrm{CDCl}_{3}\right): \delta 5 \cdot 81\left(s, 2 \mathrm{H},-\mathrm{O}-\mathrm{CH}_{2}-\mathrm{O}-\right), 6 \cdot 39$ $\left(s, 1 \mathrm{H}, \mathrm{C}_{3}-\mathrm{H}\right), 6.94\left(d, 1 \mathrm{H}, J=8.8 \mathrm{~Hz}, \mathrm{C}_{6}^{\prime}-\mathrm{H}\right), 6.68$ $\left(d, 1 \mathrm{H}, J=8.8 \mathrm{~Hz}, \mathrm{C}_{5}{ }^{\prime}-\mathrm{H}\right), 7.03-7.09\left(m, 1 \mathrm{H}, \mathrm{C}_{6}-\mathrm{H}\right)$, $6.99\left(d, 1 \mathrm{H}, J=9 \mathrm{~Hz}, \mathrm{C}_{8}-\mathrm{H}\right), 6.81\left(s, 1 \mathrm{H}, \mathrm{C}_{2}{ }^{\prime}-\mathrm{H}\right)$, 7.34-7.37 (m, 1H, $\left.\mathrm{C}_{7}-\mathrm{H}\right), 7 \cdot 61\left(d, 1 \mathrm{H}, \mathrm{J}=9 \mathrm{~Hz}, \mathrm{C}_{5}-\mathrm{H}\right)$.

2.4 Synthesis of 2-benzo[1,3]dioxol-5-yl-chromen-4one (3', 4'-methylenedioxyflavone, 6) using Ph-S-S-Ph

The chalcone $(4,1.5 \mathrm{mmol}, 402 \mathrm{mg})$ was ground with diphenyl sulphide ${ }^{12}(125 \mathrm{mg})$ in a mortar and the mixture was transferred to a $100-\mathrm{ml}$ three-necked round-bottomed flask equipped with nitrogen inlet and outlet tubes. The central neck was closed with a glass stopper. The flask was then dipped into a silicon oil bath and heated at $265^{\circ} \mathrm{C}$ under nitrogen atmosphere until distilling of the thiols formed ceased through the other outlet tube $(2.5 \mathrm{~h})$. The reaction mixture was then cooled to room temperature and $20 \mathrm{ml}$ chloroform was added. The organic layer was washed with water several times. It was dried over anhydrous sodium sulphate and the solvent removed by distillation. The product crystallized from ethanol as colourless needles (185 mg), yield 46\%, m.p. $131-132^{\circ} \mathrm{C}, R_{f} 0.59$ (benzene-acetone; $10: 1$ ). It gave blue fluorescence in UV light and positive $\mathrm{Mg} / \mathrm{HCl}$ test. Spectral data of this flavone (6) were also similar to that of the product prepared by the $\mathrm{DMSO} / \mathrm{I}_{2}$ method.

2.5 Synthesis of 2-benzo[1,3]dioxol-5-yl-chromen4-one (3', 4'- methylenedioxyflavone, 6) using $D D Q$

DDQ (155 mg) was added to the chalcone (4, $1.5 \mathrm{mmol}, 402 \mathrm{mg})$ in dry dioxane $(50 \mathrm{ml})$ and the solution refluxed for $3 \mathrm{~h}$. The product purified by preparative tlc over silica gel using petroleum spirit-benzene $(1: 2)$ as developing solvent. It crystallized from ethanol as colourless needles $(231 \mathrm{mg})$, yield $57.50 \%$, m.p. $131-132^{\circ} \mathrm{C}, R_{f} 0.59$ (benzeneacetone; $10: 1)$. It gave blue fluorescence in UV light and positive $\mathrm{Mg} / \mathrm{HCl}$ test. Spectral data of this flavone (6) were also similar to that prepared by the $\mathrm{DMSO} / \mathrm{I}_{2}$ and diphenyl sulphide method.

\subsection{Synthesis of 3-benzo[1,3]dioxol-5-yl-1-(4-} benzyloxy-2-hydroxy-phenyl)-propenone (2'-hydroxy4' - benzyloxy-3, 4-methylenedioxychalcone, 5)

The procedure is similar to the synthesis of 4 . The product is crystallized from alcohol as yellow crystals $(2.67 \mathrm{~g})$, yield $65 \cdot 50 \%$, m.p. $86-87^{\circ} \mathrm{C}$ [lit ${ }^{13}$ m.p. $86^{\circ} \mathrm{C}$ ], $R_{f} 0 \cdot 64$ (benzene-acetone; $4: 1$ ). 
Analysis (found): C, 73.42; H, 4.65\%; (Calculated for $\mathrm{C}_{23} \mathrm{H}_{18} \mathrm{O}_{5}$ ): C, $73 \cdot 79 ; \mathrm{H}, 4 \cdot 81 \%$.

UV $\lambda_{\max }^{\mathrm{MeOH}}: 225,260$ and $345 \mathrm{~nm}$.

IR $v_{\max }^{\mathrm{KBr}}: 1632,1602,1534,1521,1502,1488$, $1465,1399,1371,1288,1243,1212,1189,1127$, 1104, 1053, 1004, 977, 933, 914, 840, 808, 763, $739,698,651,612 \mathrm{~cm}^{-1}$.

${ }^{11} \mathrm{H}$ NMR $\left(\mathrm{CDCl}_{3}\right): \delta 5.22\left(s, 2 \mathrm{H},-\mathrm{CH}_{2}-\mathrm{C}_{6} \mathrm{H}_{5}\right), 5.79$ $\left(s, 2 \mathrm{H},-\mathrm{O}-\mathrm{CH}_{2}-\mathrm{O}-\right), 6.43\left(s, 1 \mathrm{H}, \mathrm{C}_{3}{ }^{\prime}-\mathrm{H}\right), 6.90(s$, $\left.1 \mathrm{H}, \mathrm{C}_{2}-\mathrm{H}\right), 6.72\left(d, 1 \mathrm{H}, J=8.6 \mathrm{~Hz}, \mathrm{C}_{5}{ }^{\prime}-\mathrm{H}\right), 6.81(d$, $\left.1 \mathrm{H}, J=9 \mathrm{~Hz}, \mathrm{C}_{5}-\mathrm{H}\right), 6.95\left(d, 1 \mathrm{H}, J=9 \mathrm{~Hz}, \mathrm{C}_{6}-\mathrm{H}\right)$, $7 \cdot 40\left(d, 1 \mathrm{H}, J=16 \mathrm{~Hz}, \mathrm{C}_{\alpha}-\mathrm{H}\right), 7 \cdot 13-7 \cdot 19(m, 5 \mathrm{H}$, $\left.-\mathrm{CH}_{2}-\mathrm{C}_{6} \underline{\mathrm{H}}_{5}\right), 7.51\left(d, 1 \mathrm{H}, J=9 \mathrm{~Hz}, \mathrm{C}_{6}^{\prime}-\mathrm{H}\right), 8.02(d$, $\left.1 \mathrm{H}, J=16 \mathrm{~Hz}, \mathrm{C}_{\beta}-\mathrm{H}\right), 12 \cdot 12\left(s, 1 \mathrm{H}, \mathrm{C}_{2}-\mathrm{OH}\right)$.

2.7 Synthesis of 2-benzo[1,3]dioxol-5-yl-7-benzyloxy-chromen-4-one (7-benzyloxy-3', 4'-methylenedioxyflavone, 7) using $\mathrm{DMSO} / \mathrm{I}_{2}$

The method is similar to that for compound $\mathbf{6}$. It was purified by preparative TLC over silica gel $\mathrm{GF}_{254}$ using hexane acetone $(10: 1)$ as developing solvent and crystallized from benzene as yellow crystals (364 mg), yield $69 \cdot 40 \%$, m.p. $103-104^{\circ} \mathrm{C}, R_{f} 0.63$ (benzene-acetone; 12:1). It gives blue fluorescence in UV light and positive $\mathrm{Mg} / \mathrm{HCl}$ test.

Analysis (found): C, 74.49; H, 4.77\%; (Calculated for $\mathrm{C}_{23} \mathrm{H}_{16} \mathrm{O}_{5}$ ) C, $74 \cdot 19 ; \mathrm{H}, 4 \cdot 30 \%$.

$\mathrm{UV} \lambda_{\max }^{\mathrm{EtOH}}: 220,270$ and $365 \mathrm{~nm}$.

IR $v_{\max }^{\mathrm{KBr}}: 1647,1617,1607,1591,1569,1516$, $1501,1484,1450,1417,1399,1380,1343,1313$, 1294, 1209, 1156, 1139, 1110, 1102, 1083, 1071, 1028, 954, 919, 859, 844, 810, 761, 742, $711 \mathrm{~cm}^{-1}$.

${ }^{1} \mathrm{H}$ NMR $\left(\mathrm{CDCl}_{3}\right): \delta 5 \cdot 20\left(s, 2 \mathrm{H},-\mathrm{CH}_{2}-\mathrm{C}_{6} \mathrm{H}_{5}\right), 5 \cdot 80$ $\left(s, 2 \mathrm{H},-\mathrm{O}-\mathrm{CH}_{2}-\mathrm{O}-\right), 6.67\left(s, 1 \mathrm{H}, \mathrm{C}_{8}-\mathrm{H}\right), 6.94(s$, $\left.1 \mathrm{H}, \mathrm{C}_{2}{ }^{\prime}-\mathrm{H}\right), 6.99\left(d, 1 \mathrm{H}, J=8.8 \mathrm{~Hz}, \mathrm{C}_{6}-\mathrm{H}\right), 6.86(d$, $\left.1 \mathrm{H}, J=9 \mathrm{~Hz}, \mathrm{C}_{5}{ }^{\prime}-\mathrm{H}\right), 6.44\left(s, 1 \mathrm{H}, \mathrm{C}_{3}-\mathrm{H}\right), 6.76(d$, $\left.1 \mathrm{H}, J=9 \mathrm{~Hz}, \mathrm{C}_{6}{ }^{\prime}-\mathrm{H}\right), 7 \cdot 05-7 \cdot 10\left(m, 5 \mathrm{H},-\mathrm{CH}_{2}-\right.$ $\left.\mathrm{C}_{6} \mathrm{H}_{5}\right), 7 \cdot 48\left(d, 1 \mathrm{H}, J=9 \mathrm{~Hz}, \mathrm{C}_{5}-\mathrm{H}\right)$.

2.8 Synthesis of 2-benzo[1,3]dioxol-5-yl-7-benzyloxy-chromen-4-one (7-benzyloxy-3', 4'-methylenedioxyflavone, 7) using $P h-S-S-P h$

The method is similar to that mentioned earlier. The product crystallizes from ethyl acetate as pale yellow needles $\left(267 \mathrm{mg}\right.$ ), yield $51 \cdot 00 \%$, m.p. $103-104^{\circ} \mathrm{C}$, $R_{f} 0.63$ (benzene-acetone; 12:1). It gives blue fluorescence in $\mathrm{UV}$ light and positive $\mathrm{Mg} / \mathrm{HCl}$ test.
Spectral data of this flavone (7) is also similar to that prepared by the $\mathrm{DMSO} / \mathrm{I}_{2}$ method.

2.9 Synthesis of 2-benzo[1,3]dioxol-5-yl-7-benzyloxy-chromen-4-one (7-benzyloxy-3', 4'-methylenedioxyflavone, 7) using $D D Q$

The method is similar to that mentioned earlier. It was crystallized from ethyl acetate as pale yellow needles $\left(325 \mathrm{mg}\right.$ ), yield $62 \cdot 00 \%$, m.p. $103-104^{\circ} \mathrm{C}, R_{f}$ 0.63 (benzene-acetone; $12: 1$ ). It gives blue fluorescence in UV light and positive $\mathrm{Mg} / \mathrm{HCl}$ test. Spectral data of this flavone (7) are also similar to that of flavone prepared by DMSO/I $\mathrm{I}_{2}$ and diphenyl sulphide method.

\subsection{Antibacterial screening}

Antibacterial activities of synthesized compounds $\mathbf{4}$, 5, 6 and 7 were studied against four human pathogenic bacteria, viz., Shigella dysenteriae $\left(\mathrm{G}^{-}\right)$, Pseudomonas aeruginosa $\left(\mathrm{G}^{-}\right)$, Sarcina lutea $\left(\mathrm{G}^{+}\right)$and Bacillus subtilis $\left(\mathrm{G}^{+}\right)$. For the detection of antibacterial activities, the filter paper disc diffusion method ${ }^{14,15}$ was used. Kanamycin was used as standard antibiotic for antibacterial activities. Nutrient agar (NA) was used as basal medium for test bacteria. The agar media were inoculated with $0.5 \mathrm{ml}$ of $24 \mathrm{~h}$ liquid cultures containing $10^{7}$ microorganisms $/ \mathrm{ml}$. Diffusion time was $24 \mathrm{~h}$ at $5^{\circ} \mathrm{C}$ for all bacteria, and incubation time was $12 \mathrm{~h}$ at $37^{\circ} \mathrm{C}$. Discs with only DMSO were used as control. Inhibitory activity was measured (in $\mathrm{mm}$ ) as the diameter of the observed inhibition zones.

\subsection{Determination of the minimum inhibitory concentration (MIC)}

Minimal inhibitory concentration is defined as the lowest concentration that inhibits bacterial growth. To determine minimum inhibitory concentration (MIC), the serial dilution technique ${ }^{16}$ was followed using nutrient broth medium. MIC values of the compound $\mathbf{6}$ and 7 were determined against Pseudomonas aeruginosa $\left(\mathrm{G}^{-}\right)$and Bacillus subtilis $\left(\mathrm{G}^{+}\right)$.

\subsection{Antifungal screening}

Antifungal activities of compounds 4, 5, 6 and 7 towards five plant pathogenic and mould fungi were studied, viz., Colletotrichum gloeosporioides Penz. 
(plant pathogen), Candida albicans (human pathogen), Aspergillus niger (mould), Aspergillus flavus (mould) and Penicillium sp. (blue mould). Antifungal activity was assessed by the poisoned food technique ${ }^{17}$ in a modified condition. ${ }^{18}$ Fluconazole $(200 \mu \mathrm{g} / \mathrm{disc})$ was used as standard fungicide. Potato dextrose agar (PDA) was used as basal medium for test fungi. Glass petridishes used were sterilized. Sterilized melted PDA medium $\left(\sim 45^{\circ} \mathrm{C}\right)$ was poured at the rate of $15 \mathrm{ml}$ into each petridish $(90 \mathrm{~mm})$. After solidification of the medium, small portions of the mycelium of each fungus were spread carefully over the centre of each PDA plate with the help of sterilized needles. Thus, each fungus was transferred to a number of PDA plates, which were then incubated at $(25 \pm 2)^{\circ} \mathrm{C}$ and ready for use after five days of incubation. Prepared discs of samples were placed gently on solidified agar plates, freshly seeded with the test organisms with sterile forceps. A control disc was also placed on the test plates to compare the effect of the test samples and to nullify the effect of solvent respectively. The plates were then kept in a refrigerator at $4^{\circ} \mathrm{C}$ for $24 \mathrm{~h}$ so that the materials had sufficient time to diffuse over a considerable area of the plates. After this, the plates were incubated at
$37 \cdot 5^{\circ} \mathrm{C}$ for $72 \mathrm{~h}$. Dimethyl sulphoxide (DMSO) was used as solvent to prepare desired solutions $(10 \mathrm{mg} /$ $\mathrm{ml}$ ) of the compounds initially and also to maintain proper control.

\section{Results and discussion}

3.1 Synthesis of 2-benzo[1,3]dioxol-5-yl-chromen4-one and 2-benzo[1,3]dioxol-5-yl-7-benzyloxychromen-4-one

Syntheses of 3',4'-methylenedioxyflavone (2-benzo$[1,3]$ dioxol-5-yl-chromen-4-one) and 7-benzyloxy3',4'-methylenedioxyflavone (2-Benzo[1,3]dioxol-5yl-7-benzyloxy-chromen-4-one) were accomplished starting from 2-hydroxyacetophenone (1) and 2hydroxy-4-benzyloxyacetophenone ${ }^{19}$ (2) respectively, as shown in scheme 1 .

Alkaline condensation of 2-hydroxyacetophenone (1) and 3, 4-methylenedioxybenzaldehyde (3) yielded 2'-hydroxy-3,4-methylenedioxychalcone (4). It was obtained as pale yellow crystals, m.p. $124-127^{\circ} \mathrm{C}$. The structure of this chalcone (4) has been confirmed by spectral data and elemental analysis. The UV ab-

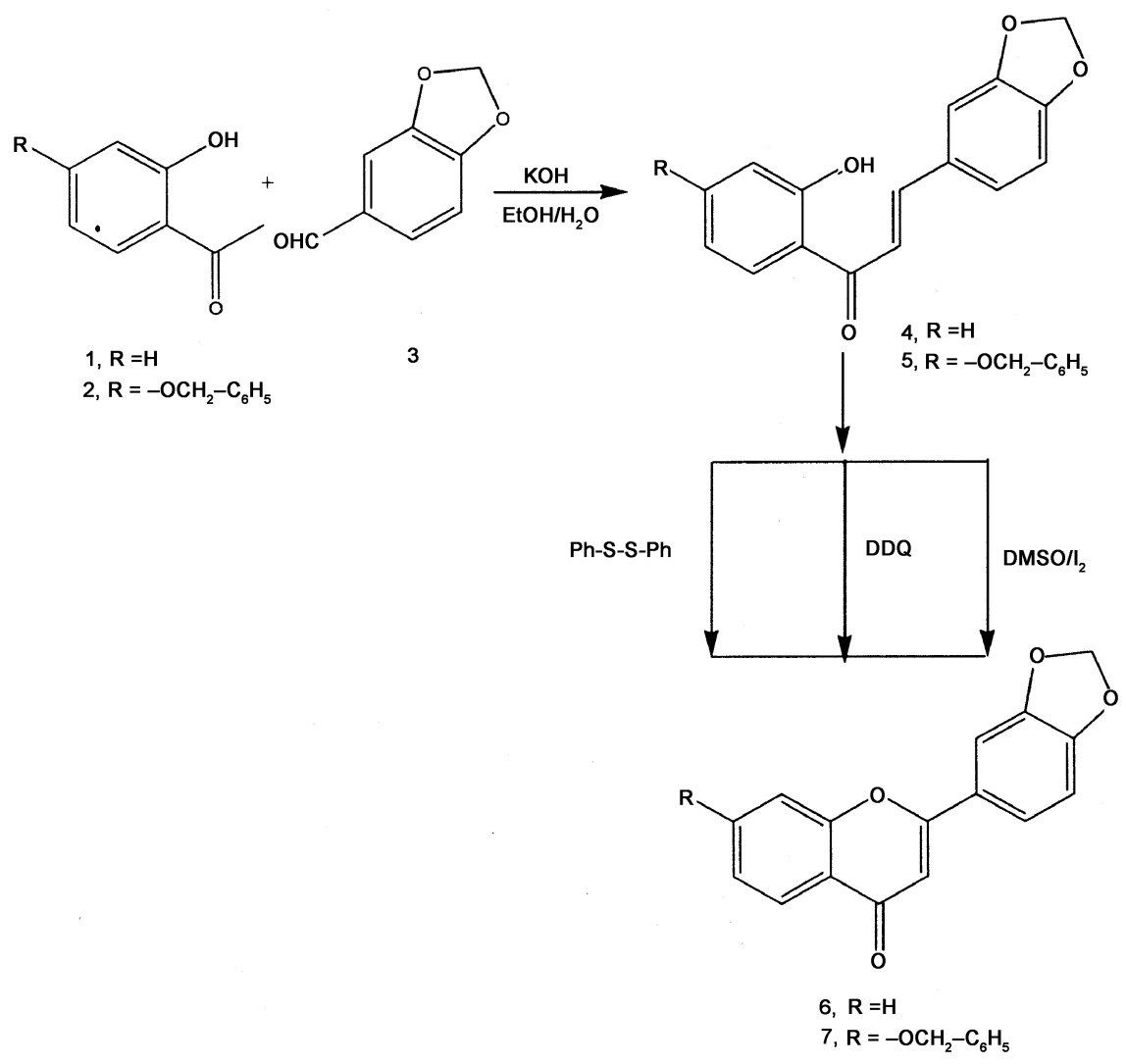

Scheme 1. 
sorption band of $4\left(\lambda_{\max } 230,265\right.$ and $\left.355 \mathrm{~nm}\right)$ suggests the presence of a chalcone skeleton. It gives brown color with alcoholic ferric chloride solution but no IR absorption band for hydroxyl group (-OH), at $\mathrm{C}-2$ position. ${ }^{20}$ This is supported by (i) a relatively weaker IR band at $1640 \mathrm{~cm}^{-1}$ (chelated $>\mathrm{C}=\mathrm{O}$ ), and (ii) an appropriately deshielded phenolic proton signal at $\delta 11.58(1 \mathrm{H}, s)$, exchangeable with $\mathrm{D}_{2} \mathrm{O}$. In the ${ }^{1} \mathrm{H}$ NMR spectrum, the methylene protons of the methylenedioxy group (-O- $\left.\mathrm{CH}_{2}-\mathrm{O}-\right)$ appear as a singlet at 5.74 integrating for two protons, the three aromatic protons of the $\mathrm{B}$ ring, which appear at $\delta$ $6.65\left(d, 1 \mathrm{H}, J=8.7 \mathrm{~Hz}, \mathrm{C}_{5}-\mathrm{H}\right), 6.83\left(s, 1 \mathrm{H}, \mathrm{C}_{2}-\mathrm{H}\right)$ and $6.92\left(d, 1 \mathrm{H}, J=8.7 \mathrm{~Hz}, \mathrm{C}_{6}-\mathrm{H}\right)$ integrating for one proton each. The four aromatic protons of the $\mathrm{A}$ ring appear as two double doublets and two multiplets at $\delta 6.97(d, 1 \mathrm{H}, J=9 \mathrm{~Hz}), 7.60(d, 1 \mathrm{H}$, $J=9 \mathrm{~Hz}), 7 \cdot 01-7 \cdot 07(m, 1 \mathrm{H})$ and 7.31-7.37 $(m, 1 \mathrm{H})$ assigned to $\mathrm{C}_{3}{ }^{\prime}, \mathrm{C}_{6}{ }^{\prime}, \mathrm{C}_{5}{ }^{\prime}$ and $\mathrm{C}_{4}{ }^{\prime}$ protons respectively. The $\mathrm{C}_{\alpha}-\mathrm{H}$ and $\mathrm{C}_{\beta}-\mathrm{H}$ protons of $\mathbf{4}$ appeared as two doublets at $\delta 7.41(J=16 \mathrm{~Hz})$ and $8.01(J=16 \mathrm{~Hz})$ integrating for one proton each.

Oxidation of chalcone 4 into the corresponding flavone $\mathbf{6}$ was carried out differently by using $\mathrm{DMSO} / \mathrm{I}_{2}$, diphenyl sulphide and DDQ. Flavone 6 was obtained as yellow needles, m.p. $131-132^{\circ} \mathrm{C}$. The structure of this flavone $\mathbf{6}$ has been confirmed by spectral data and elemental analysis. The UV absorption band of $\mathbf{6}\left(\lambda_{\max } 232,281\right.$ and $\left.370 \mathrm{~nm}\right)$ suggests the presence of a flavone skeleton. IR absorption frequency at $v 1647 \mathrm{~cm}^{-1}$ shows the presence of a carbonyl group $(>\mathrm{C}=\mathrm{O})$ and absence of a hydroxyl group band confirms the oxidation of chalcone 4 into flavone $\mathbf{6}$. The ${ }^{1} \mathrm{H}$ NMR spectrum of flavone $\mathbf{6}$ indicates the presence of a methylenedioxy group $\left(-\mathrm{O}-\mathrm{CH}_{2}-\mathrm{O}-\right)$ that appears as a singlet at $\delta 5.81$ integrating for two protons. The three aromatic protons of the $\mathrm{B}$ ring which appear at $\delta 6.68(d, 1 \mathrm{H}$, $\left.J=8.8 \mathrm{~Hz}, \mathrm{C}_{5}{ }^{\prime}-\mathrm{H}\right), 6.81\left(s, 1 \mathrm{H}, \mathrm{C}_{2}{ }^{\prime}-\mathrm{H}\right)$ and $6.94(d$, $1 \mathrm{H}, J=8.8 \mathrm{~Hz}, \mathrm{C}_{6}{ }^{\prime}-\mathrm{H}$ ) integrate for one proton each. The other four aromatic protons of the A ring appear as two double doublets and two multiplets at $\delta 6.99$ $(d, 1 \mathrm{H}, J=9 \mathrm{~Hz}), 7.61(d, 1 \mathrm{H}, J=9 \mathrm{~Hz}), 7 \cdot 03-7.09$ $(m, 1 \mathrm{H})$ and $7 \cdot 34-7.39(m, 1 \mathrm{H})$ and are assigned to $\mathrm{C}_{8}, \mathrm{C}_{5}, \mathrm{C}_{6}$ and $\mathrm{C}_{7}$ protons respectively. The $\mathrm{C}_{3}-\mathrm{H}$ proton of the flavone nucleus appears as a singlet at $\delta 6.39$ integrating for one proton.

Base-catalysed aldol-condensation of 2-hydroxy4-benzyloxyacetophenone (2) and 3,4-methylenedioxybenzaldehyde (3) gives 2'-hydroxy-4'-benzyloxy3,4-methylenedioxy chalcone ${ }^{13}(\mathbf{5})$. The chalcone 5 is obtained as yellow crystals, m.p. $86-87^{\circ} \mathrm{C}$ [Lit. ${ }^{13}$ m.p. $86^{\circ} \mathrm{C}$ ]. UV absorption maxima of $\mathbf{5}$ occur at 225, 260 and $345 \mathrm{~nm}$. IR absorption peaks of 5 due to carbonyl group appear at $1632 \mathrm{~cm}^{-1}$ but no IR absorption band is seen for hydroxyl group $(-\mathrm{OH})$, at C-2 position ${ }^{20}$. Spectral data $\left({ }^{1} \mathrm{H}\right.$ NMR, UV and IR, see §2) and elemental analysis confirm the structure of compound 5 as 3-benzo[1,3]dioxol-5-yl-1-(4-benzyloxy-2-hydroxy-phenyl)-propenone (2'-hydroxy-4'benzyloxy-3,4-methylenedioxychalcone).

Cyclization of chalcone 5 into the corresponding flavone 7 was also carried out differently by using DMSO/I $\mathrm{I}_{2}$, diphenyl sulphide and DDQ. Flavone $\mathbf{7}$ is obtained as yellow crystals, m.p. $103-104^{\circ} \mathrm{C}$. The structure of this flavone 7 has been supported by spectral data and elemental analysis. The UV spectrum of this flavone 7 ( $\lambda_{\max } 220,270$ and $365 \mathrm{~nm}$ ) suggests the presence of a flavone nucleus. IR absorption frequency at $v 1647 \mathrm{~cm}^{-1}$ shows the presence of a carbonyl group $(>\mathrm{C}=\mathrm{O})$ and the absence of a hydroxyl group band, confirming the oxidation of chalcone 5 into flavone 7, which is also supported by the ${ }^{1} \mathrm{H}$ NMR spectrum of flavone 7 . The ${ }^{1} \mathrm{H}$ NMR spectrum of 7 explains the presence of a methylenedioxy group $\left(-\mathrm{O}-\mathrm{CH}_{2}-\mathrm{O}-\right)$ that appear as a singlet at 5.80 integrating for two protons. Methylene and aromatic protons of a benzyloxy group indicated by a singlet at $\delta 5.20\left(2 \mathrm{H},-\mathrm{O}-\mathrm{CH}_{2}-\mathrm{C}_{6} \mathrm{H}_{5}\right)$ and a multiplet at $\delta$ 7.05-7.10 $\left(2 \mathrm{H},-\mathrm{O}-\mathrm{CH}_{2}-\mathrm{C}_{6} \mathrm{H}_{5}\right)$ integrating for two and five protons, respectively. The three aromatic protons of the $\mathrm{B}$ ring which appear at $\delta 5.50(d, 1 \mathrm{H}$, $\left.J=8.6 \mathrm{~Hz}, \mathrm{C}_{5}{ }^{\prime}-\mathrm{H}\right), 5.20\left(\mathrm{~s}, 1 \mathrm{H}, \mathrm{C}_{2}{ }^{\prime}-\mathrm{H}\right)$ and $5.79(d$, $\left.1 \mathrm{H}, J=8.6 \mathrm{~Hz}, \mathrm{C}_{6}^{\prime}-\mathrm{H}\right)$ integrating for one proton each respectively. The three aromatic protons of $\mathrm{A}$ ring appear as an $\mathrm{ABC}$ system at $\delta 6.67\left(s, 1 \mathrm{H}, \mathrm{C}_{8-}\right.$ $\mathrm{H}), 6.99\left(d, 1 \mathrm{H}, J=8.8 \mathrm{~Hz}, \mathrm{C}_{6}-\mathrm{H}\right)$ and $7.48(d, 1 \mathrm{H}$, $\left.J=8.8 \mathrm{~Hz}, \mathrm{C}_{5}-\mathrm{H}\right)$ integrating for one proton each. The flavone 7 also gives a characteristic singlet at $\delta$ $6 \cdot 44$, assigned to the $\mathrm{C}_{3}-\mathrm{H}$ proton.

Among the methods used for oxidation of chalcones $(\mathbf{4}$ and $\mathbf{5})$ into their corresponding flavones (6 and 7), the $\mathrm{DMSO} / \mathrm{I}_{2}$ method gave the highest yield compared to the two other oxidizing methods, while the diphenyl sulphide method gave the lowest yield.

\subsection{Antibacterial activities}

The antibacterial activities of compounds $4,5,6$, and 7 have been assayed at the concentration of $100 \mu \mathrm{g} /$ disc, $200 \mu \mathrm{g} / \mathrm{disc}$ and $300 \mu \mathrm{g} / \mathrm{disc}$ against four human pathogenic bacteria. Among them, two were 
Table 1. Antibacterial screening for compounds 4, 5, 6 and 7.

\begin{tabular}{lcccccc}
\hline \multirow{2}{*}{ Name of the organisms } & $\begin{array}{c}\text { Concentration } \\
(\mu \mathrm{g} / \mathrm{disc})\end{array}$ & $\mathbf{4}$ & $\mathbf{5}$ & $\mathbf{6}$ & $\mathbf{7}$ & $\mathrm{K}-30^{*}$ \\
\cline { 3 - 6 } Shigella dysenteriae & 100 & - & - & - & - & 26 \\
& 200 & - & - & - & - & \\
Pseudomonas aeruginosa & 300 & - & - & 6 & 6 & \\
& 100 & - & - & - & - & 28 \\
Sarcina lutea & 200 & - & - & - & - & \\
& 300 & - & - & 11 & 11 & \\
Bacilus subtillis & 100 & - & - & - & - & 34 \\
& 200 & - & - & - & - & \\
& 300 & - & - & 7 & - & 30 \\
& 100 & - & - & - & - & 30 \\
& 200 & - & - & - & - & \\
& 300 & - & - & 7 & 8 & \\
\hline
\end{tabular}

*Kanamycin $-30 \mu \mathrm{g} / \mathrm{disc}$

Table 2. Antifungal screening for compounds 4, 5, 6, and 7 .

\begin{tabular}{|c|c|c|c|c|c|c|}
\hline \multirow[b]{2}{*}{ Name of the organisms } & \multirow[b]{2}{*}{$\begin{array}{l}\text { Concentration } \\
(\mu \mathrm{g} / \text { disc })\end{array}$} & \multicolumn{5}{|c|}{ Diameter of the zone of inhibition (mm) } \\
\hline & & 4 & 5 & 6 & 7 & $\begin{array}{l}\text { Fluconazole } \\
(200 \mu \mathrm{g} / \mathrm{disc})\end{array}$ \\
\hline Penicillium sp. & $\begin{array}{l}100 \\
200 \\
300\end{array}$ & $\begin{array}{r}- \\
8 \\
11\end{array}$ & $\begin{array}{l}- \\
- \\
7\end{array}$ & $\begin{array}{r}- \\
6 \\
10\end{array}$ & $\begin{array}{c}- \\
- \\
6\end{array}$ & - \\
\hline Aspergillus niger & $\begin{array}{l}100 \\
200 \\
300\end{array}$ & $\begin{array}{l}- \\
- \\
-\end{array}$ & $\begin{array}{l}- \\
- \\
-\end{array}$ & $\begin{array}{l}- \\
- \\
-\end{array}$ & $\begin{array}{l}- \\
- \\
-\end{array}$ & - \\
\hline Aspergillus flavus & $\begin{array}{l}100 \\
200 \\
300\end{array}$ & $\begin{array}{l}- \\
- \\
-\end{array}$ & $\begin{array}{l}- \\
- \\
-\end{array}$ & $\begin{array}{l}- \\
- \\
-\end{array}$ & $\begin{array}{l}- \\
- \\
-\end{array}$ & 10 \\
\hline Candida albicans & $\begin{array}{l}100 \\
200 \\
300\end{array}$ & $\begin{array}{l}- \\
- \\
-\end{array}$ & $\begin{array}{l}- \\
- \\
-\end{array}$ & $\begin{array}{l}- \\
- \\
-\end{array}$ & $\begin{array}{l}- \\
- \\
-\end{array}$ & - \\
\hline Colletotrichum gloeosporioides & $\begin{array}{l}100 \\
200 \\
300\end{array}$ & $\begin{array}{l}- \\
- \\
-\end{array}$ & $\begin{array}{l}- \\
- \\
5\end{array}$ & $\begin{array}{l}- \\
- \\
-\end{array}$ & $\frac{-}{-}$ & - \\
\hline
\end{tabular}

gram-positive and the other two were gram-negative. The inhibitory effects of compounds $\mathbf{4}, \mathbf{5}, \mathbf{6}$, and 7 against these organisms are given in table 1 .

The screening results indicate that compounds 4 and $\mathbf{5}$ do not show any antibacterial activity to the bacteria tested. Compound $\mathbf{6}$ has low antibacterial activity towards every bacteria tested, at a concentration of $300 \mu \mathrm{g} / \mathrm{disc}$, while compound 7 also has low antibacterial activity against Shigella dysenteriae, Pseudomonas aeruginosa and Bacilus subtillis and no activity against Sarcina lutea. From the above result, it can be concluded that the antibacterial acti- vities of compound $\mathbf{6}$ and $\mathbf{7}$ are due to the flavone skeleton.

\subsection{Minimum inhibitory activity}

The minimum inhibitory concentration of compounds 6 and 7 were determined against Bacilus subtillis and Pseudomonas aeruginosa by the serial dilution method. The MIC levels of both compounds 6 and 7 were found $256 \mu \mathrm{g} / \mathrm{mL}$ against Bacilus subtillis and Pseudomonas aeruginosa, respectively. 


\subsection{Antifungal activities}

The antifungal activities of compounds $\mathbf{4}, \mathbf{5}, \mathbf{6}$, and $\mathbf{7}$ have been assayed at concentrations of $100 \mu \mathrm{g} / \mathrm{disc}$, $200 \mu \mathrm{g} / \mathrm{disc}$ and $300 \mu \mathrm{g} / \mathrm{disc}$ against five plant pathogens and mould fungi. The inhibitory effects of compounds $4,5,6$, and $\mathbf{7}$ against these organisms are given in table 2 .

The screening results indicate that compounds 4 and $\mathbf{6}$ do not show any antifungal activities against Aspergillus niger, Aspergillus flavus, Candida albicans and Colletotrichum gloeosporioides while they show good antifungal activities at high concentration against only Penicillium sp. in comparison with standard fungicides, fluconazole. Whereas compounds 5 and $\mathbf{7}$ showed antifungal activities at high concentration against Penicillium sp. and Colletotrichum gloeosporioides whereas standard fungicide fluconazole did not show any antifungal activities against Penicillium sp. and Colletotrichum gloeosporioides.

\section{Acknowledgements}

The author thanks Prof. Sung Hoon Kim, Konkuk University, Seoul, Korea for recording the ${ }^{1} \mathrm{H}$ NMR spectra of the synthesized compounds and also Dr M Shahidul Alam for encouragement.

\section{References}

1. Rhajaouri M, Oumzil H, Faid M, Lyagoubi M, Elyachioui M and Benjouad A 2001 Science Lett. 3

2. Miroslawa K-B and Marian W 2003 Z. Naturforsch C58 65
3. Weidenbörner M and Jha H C C 2003 Int. Symp. on Natural phenols in Plant Resistance, Int. Soc. Horticultural Sci. Acta Horticulture, p 381

4. Tanaka T, Iinuma M, Yuki K, Fujii Y and Mizuno M 1992 Phytochemistry 31993

5. Vender Berghe D A R, Haemers A and Vlieunek A J 1993 In Bioactive natural products; Detection and structural determination (eds) S M Colegate and K J Molyneux (London: CRC Press) ch. 17, pp 405440

6. Bors W, Heller W, Michel C and Saran M 1990 In Methods in enzymology (eds) L Packer and A N Glazer (New York: Academic Press) vol 186, pp 343-355

7. Alam S, Sarkar Z and Islam A 2004 J. Chem. Sci. 11629

8. Alam S, Miah M A J and Islam A 2004 J. Biol. Sci. 4 527

9. Alam S 2004 Acta Chim. Slov. 200451 (in press)

10. Alam S, Miah M A J and Islam A 2004 ACGC Chem. Res. Commun. 17 (in press)

11. Doshi A G, Soni P A and Ghiya B J 1986 Indian J. Chem. 258759

12. Hoshino Y, Ohinata T and Taken N 1986 Bull. Chem. Soc. (Jpn) $\mathbf{5 9} 2351$

13. Mahal H S, Raj H S and Venkataraman K $1935 \mathrm{~J}$. Chem. Soc. 1965

14. Arima H, Ashida H and Danno G-I 2002 Biosci. Biotechnol. Biochem. 661014

15. Jeongmok K, Maurice R M and Cheng I W $1995 \mathrm{~J}$. Agric. Food Chem. 432834

16. Nishina C, Enoki N, Tawata S, Mori A, Kobayashi K and Fukushima M 1987 Agric. Biol. Chem. 51139

17. Grover R K and Moore J D 1962 Phytopathology 52 876

18. Miah M A T, Ahmed H U, Sharma N R, Ali A and Miah S A 1990 Bangladesh J. Bot. 195

19. Aneja R, Khanna R N and Sheshadri T R 1963 J. Chem. Soc. 163

20. Talapatra S K, Mallik A K and Talapatra B 1980 Phytochemistry 191199 